Lina Hellberg är licentiand i FoRFa- forskarskola för kommunikation och relationer som grundläggande för barns lärande. Hon har sin bakgrund i förskolan som förskollärare med ett intresse för hur naturvetenskap som innehåll kan förstås i ett förskolesammanhang. Speciellt intresserar hon sig för hur förskollärares kunnande i naturvetenskap påverkar undervisning i fysik.

Susanne Thulin är docent och bitr professor i pedagogik och undervisar på förskollärarutbildningen vid Högskolan Kristianstad. Susanne är också leg förskollärare. Hennes forskningsintressen är inriktat mot undervisning av naturvetenskap i förskolan.

Andreas Redfors är docent och professor i fysik - inriktning fysikdidaktik. Han har ämneslärarexamen och doktorsexamen i fysik vid Lunds universitet. Han undervisar i fysik, astronomi och naturvetenskapernas didaktik, främst inom lärarutbildning. Han leder forskargruppen Learning in Science and Mathematics. Hans huvudsakliga forskningsintresse är naturvetenskapens natur, med speciellt fokus på betydelsen av teoretiska modeller för lärande och undervisning av fysik, såväl med som utan stöd av digitala tekniker.

\title{
LINA HELLBERG
}

Högskolan Kristianstad

lina.hellberg@hkr.se

\section{SUSANNE THULIN}

Högskolan Kristianstad

susanne.thulin@hkr.se

\section{ANDREAS REDFORS}

\section{Förskollärares konstruktion av ett fysikaliskt lärandeobjekt}

\begin{abstract}
In 2010 the Swedish national curriculum was revised and learning goals concerning chemistry and physics were introduced. That has induced a need for further understanding of teaching and learning of specific content in preschool. Focus in this article is how physics content is constructed as an object of learning during preschool teachers' planning of teaching. The result of a phenomenographic analysis focusing themes of the conversation concerning the intended object of learning reveals a complex process. Occurrences in the activities with the children, available tools at the preschool, the preschool teachers' perceptions of the mission and understanding of the learning object, contribute to the construction of the learning object. All these aspects are discussed and implications for preschool practice are suggested.
\end{abstract}

\section{BAKGRUND}

Arbete med naturvetenskap har på olika sätt varit en del av svensk förskola över tid. Gustavsson och Thulin (2017) beskriver att det historiskt till stor del har handlat om ett arbete med djur och natur och då Svensk förskola fick sin första läroplan, Lpfö, 1998 (Utbildningsdepartementet, 1998) formul- 
erades också mål som rörde miljö och ekologiska perspektiv. En reviderad läroplan 2011 har emellertid inneburit ett vidgat uppdrag gällande naturvetenskap med specifikt uttryckta strävansmål mot att varje barn "utvecklar sin förståelse för naturvetenskap och samband i naturen, liksom sitt kunnande om växter, djur samt enkla kemiska processer och fysikaliska fenomen" (Skolverket, 2010a). I samband med ett vidgat uppdrag för förskolan har frågor som rör val av innehåll och didaktiska angreppssätt kommit på agendan (Skolverket, 2010b; Skolinspektionen, 2018; Thulin, 2011). Föreliggande studie tar sin utgångspunkt i ovanstående och har som syfte att studera hur ett lärandeobjekt om fysikaliska fenomen konstrueras i samtal mellan förskollärarna vid planering av undervisning av ett fysikaliskt fenomen med barn i ålder 1-3 år.

\section{Förskollärares kompetens}

I en kunskapsöversikt om lärande i förskolan och grundskolans tidigare år synliggörs hur utbildningskvalitet påverkas av lärares pedagogiska och ämnesmässiga kompetens, samt förmåga att skapa en dialog med barnen (Skolverket, 2010b). En professionell lärare kännetecknas av kompetens om barn, lärande och ämnesinnehåll (Pramling Samuelsson \& Sheridan, 2016; Thulin \& Redfors, 2017). För undervisning av ett innehåll har förskollärares föreställningar om uppdrag, vad barn i förskolan ska och kan lära sig, samt lärares kunskaper om innehåll och didaktik beskrivits som betydelsefullt och grundläggande kapacitet för förändring (Fleer, 2009; Thulin, 2011; Campbell \& Spelderwinde, 2018). Det handlar om ett kunnande om såväl naturvetenskapliga förklaringsmodeller som barns lärande och didaktik (Redfors, 2016). Förskollärares didaktiska skicklighet och deras förmåga att skapa förutsättningar för barnen att reflektera och forma sin egen förståelse är grundläggande för naturvetenskaplig kunskapsutveckling (Larsson, 2013). Thulin (2011) ger uttryck för att naturvetenskap i förskolan även handlar om att läraren innehar en ömsesidig samtidighet. Detta innebär att som förskollärare vara öppen för, utgå ifrån och använda barns perspektiv som utgångspunkt för samtal och arbete och samtidigt ha lärandeobjektet i fokus. Syftet med detta förhållningssätt är att möjliggöra kopplingar mellan barns erfarenheter och det lärandeobjekt som är i fokus för undervisningen. En annan viktig aspekt är främjandet av positiva förebilder. Genom att barnen får möta positiva lärare som de kan identifiera sig med kan såväl intresse som positiv inställning till innehållet utvecklas (Pramling Samuelsson \& Sheridan, 2016).

\section{Naturvetenskap i förskolan}

Ur ett samhällsperspektiv kan det uppfattas som problematiskt när ungdomar inte uppvisar intresse för naturvetenskap eller har svårt att förstå dess innebörd eller betydelse. Attityd och intresse för naturvetenskap bland ungdomar har också undersökts genom Relevans of Science Education (ROSE), (Oskarsson, 2011), som diskuterar att de frågeställningar som mest intresserar eleverna sällan är utgångspunkt för undervisningen. Att i undervisningssammanhang visa på hur naturvetenskap, dess begrepp och samband är en viktig del av vårt samhälle är något som beskrivs kunna stimulera ungdomarnas intresse. Oskarsson (2011) poängterar att om skolan kan fånga ungdomars intresse och möta de frågor de har så kan intresset för det naturvetenskapliga innehållet i skolan öka. Eshach och Fried (2005) hänvisar till flera studier som visar på en negativ attityd till naturvetenskap även bland lärare för barn och yngre elever. Ett sätt att på sikt förändra dessa negativa strömningar är att bidra till utvecklingen av naturvetenskaplig undervisning i förskolan, men samtidigt slå vakt om förskolans särart (Thulin, 2015; Areljung \& Sundberg, 2018).

Att införa naturvetenskap i syfte att öka elevers intresse för naturvetenskaplig utbildning kan förknippas med ett sätt att se på barn som becoming där barn ses vara på en resa mot något mer fulländat i framtiden (Halldén, 2007). Målet finns då utanför barnets här och nu situation och hänvisas till framtiden. Ett annat sätt att se på barn är att se dem som beings. Barnet ses då utifrån ett här- och nuperspektiv. Om barn ses som beings i relation till lärande om naturvetenskap ges barn möjlighet att utforska och förstå den omvärld och tillvaro de befinner sig i för stunden. Målet knyts närmare barnet och den lärmiljö de befinner sig i. Utifrån detta perspektiv betraktas barn som kompetenta och som sociala aktörer som kan lära i samspel med omgivningen (Halldén, 2007). Vilket av dessa perspektiv som dominerar en lärares eller ett arbetslags inställning kan påverka val av didaktiska angreppssättet i relation till det naturvetenskapliga innehållet (Redfors, 2016). 
Harlen (2010) poängterar att i arbete med naturvetenskap bör lärare identifiera lärandemål avseende grundläggande och övergripande idéer utifrån vilka olika naturvetenskapliga fenomen kan förstås och förklaras. Redfors (2016) diskuterar detta i termer av teoretiska förklaringsmodellers betydelse för arbete med naturvetenskap i förskolan. De teoretiska modellerna finns på olika nivåer för att beskriva fenomen i omvärlden. I förskolan bör en teoretisk modell vara utformad på en nivå som passar både förskollärare och barn. De förklaringsmodeller som väljs att arbeta med syftar till att hjälpa barnen att förstå sin omvärld just där och då, men också att utgöra en grund för fortsatt utveckling. Med denna utgångspunkt behöver arbetslag i förskolan diskutera den teoretiska förklaringsmodell som är kopplad till det fenomen som de tänker arbeta med i undervisningssituationen. Den gemensamt valda förklaringsmodellen bör utgöra ett ramverk för förutsägelser och diskussion (ibid). Larsson (2016) beskriver i samma anda att oavsett vilken stöttning förskollärarna ger barnen i aktiviteter med ett abstrakt fysikaliskt fenomen så är barnen engagerade. Men, trots att barnen sysselsätter sig med naturvetenskapliga aktiviteter visar hennes resultat att det inte alltid är så att barnen möts didaktiskt på ett sådant sätt att de innehållsliga aspekterna gällande fysik kommer i förgrunden. Hon betonar att det blir svårt för barnen att utveckla sitt kunnande om inte innehållet blir föremål för samtal och utforskande (ibid). Att vara i ett sammanhang och tillsammans med andra barn och förskollärare undersöka och diskutera ett naturvetenskapligt innehåll kan kopplas till det som Thulin (2011, s 80) beskriver som att "göra naturvetenskap i förskolan".

Utifrån i detta avsnitt beskrivna förutsättningar framgår betydelsen av att barn och förskollärare tillsammans etablerar en grund för utvecklande av kunnande om naturvetenskapliga lärandeobjekt. Vikten av att arbetslag utvecklar undervisning i naturvetenskap utifrån val av specifikt innehåll, förklaringsmodell och arbetssätt synliggörs samt att förskollärares attityder till och kunskaper i naturvetenskap och naturvetenskapernas didaktik påverkar arbetet med innehållet.

\section{TEORETISKT RAMVERK}

Studien utgår ifrån en fenomenografisk ansats där variationer av förskollärares uppfattningar under planering av undervisning av ett fysikaliskt fenomen har studerats. Inom fenomenografi riktas intresset mot hur individer uppfattar fenomen i omvärlden. Specifikt innebär det ett intresse för variationen i och förändringarna av förmågan att erfara världen, eller snarare förmågan att erfara specifika fenomen i världen på kvalitativt olika sätt (Marton \& Booth, 2000). Variation är centralt för att urskilja något (Marton, Runesson \& Tsui, 2004) och kan ses som lärandets drivkraft (Marton \& Booth, 2000). En lärare behöver enligt Marton m.fl. (2004) veta vad det är för innehåll, färdigheter och förmågor barn ska lära sig i en speciell situation, samt vad det innebär att kunna eller lära sig just detta. Lärande identifieras som utvecklat/förändrat kunnande av något. För att den lärande ska kunna identifiera ett specifikt lärandeobjekt behöver medvetandet riktas mot objektet och kritiska aspekter kunna urskiljas. Då läraren identifierat vilket innehåll, färdigheter och förmågor barnen ska lära sig, det intentionella lärandeobjektet (intented object of learning) genomför läraren sin undervisning vilket benämns det iscensatta lärandeobjektet (enacted object of learning). Det som barnen möter i situationen, vad de riktar fokus mot och vad de verkligen lär sig utgör det upplevda lärandeobjektet (lived object of learning). Här utgör det fysikaliska fenomenet som lärarna planerar undervisning av och de aktuella aktiviteterna aktuellt lärandeobjekt. Innehållet i det fysikaliska fenomenet ses som det direkta lärandeobjektet medan de förmågor och färdigheter som är kopplade till aktiviteten som undersökande frågor, hypotesprövning, reflekterande ställningstagande ses som det indirekta lärandeobjektet (Marton, mfl 2004). Fokus för denna artikel är hur det intentionella lärandeobjektet konstrueras under lärarnas planeringssamtal.

Linell (1982) beskriver hur det i kulturer utvecklas normer kring hur något ska vara eller göras. Inom en kultur utvecklas även föreställningar och värderingar kopplade till specifika sammanhang och aktiviteter. Förskolan kan beskrivas som en kultur i den mening att det är en social gemenskap, där förskollärarna som grupp ingår, som kommunicerar, ibland omedvetna normer, kring aktiviteter eller beteende (Linell, 1982). Språket är ett diskursivt redskap som gör det möjligt att dela upplevelser av 
vad som hänt i en viss situation. Uttalanden som görs grundar sig i tidigare erfarenheter men möjliggör även nya erfarenheter genom att andra ger respons på det som sagts (ibid). De individer som deltar i ett socialt sammanhang bidrar till att upprätthålla strukturen. Strukturer i sig är inte bestämmande utan ska förstås som något som konstrueras i en viss tid och plats av olika aktörer (Halldén, 2007, sid 29). De aktuella förskollärarnas uttalanden under arbetslagsplanering kan ses i ljuset av detta. Förskollärarna bidrar med sina erfarenheter och uppfattningar till diskussionen om innehållet för att identifiera vad lärandeobjektet ska vara samt hur det ska erbjudas för barnen, d.v.s. de konstruerar det intentionella lärandeobjektet.

\section{Syfte och frågeställning}

Det övergripande syftet med denna studie är att utveckla kunskap om hur ett fysikaliskt lärandeobjekt konstrueras i förskolans kontext. I denna artikel undersöks det intentionella lärandeobjektet och aktuell forskning fråga är:

- Hur konstrueras ett fysikaliskt innehåll som lärandeobjekt i samtal under ett arbetslags planering av undervisning?

\section{METOD OCH ANALYS}

Nedan presenteras studiens design, urval och datainsamling. Begrepp för analys och forskningsetiska principer beskrivs.

\section{Studiens design}

Studien är genomförd i ett arbetslag med tre förskollärare på en förskola belägen utanför en mellanstor stad i södra Sverige. De aktuella förskollärarna har samma utbildning, de är alla legitimerade förskollärare. Studien fokuserar på det intentionella lärandeobjektet (Marton, Runesson \& Tsui, 2004; Lo, 2014) av ett fysikaliskt lärandeobjekt. Som en utgångspunkt för att identifiera lärandeobjektet erbjuds förskollärarna en föreläsning om förklaringsmodeller inom fysik kopplade till arbete i förskola. Efter föreläsningen kom förskollärare och forskarna tillsammans överens om vilket naturvetenskapligt fenomen som skulle erbjudas barnen. Därefter enades förskollärarna om strukturen för sin undervisning för att sedan varje vecka träffas för att diskutera det genomförda och planera nästkommande undervisningstillfällen. Förskollärarna organiserade barnen i två grupper. En förskollärare undervisade grupp ett och hade vid vissa tillfällen stöd av en av de andra två förskollärarna. Dessa två förskollärare alternerade om att undervisa grupp två. En schematisk överblick visas i figur 1.

\section{Datainsamling}

Insamling av det empiriska materialet ägde rum under fyra veckor våren 2016. Datainsamling skedde genom video- och audioinspelning av fyra arbetslagsplaneringar när arbetslaget avsatt tid för diskussioner av genomförda och kommande undervisningsinsatser. Datamaterialet består av fyra videoinspelningar (30-60 min). Totalt omfattar materialet 2 timmar och 50 minuter. Vetenskapsrådets (2015) forskningsetiska principer har följts och samtliga namn i studien är fingerade.

\section{Kraft och rörelse som intentionellt objekt för lärande}

Förskollärarna har i dialog med forskarna identifierat kraft och rörelse som det intentionella lärandeobjektet, specifikt fokus är kraft och friktion i samband med lek med rutschkana. Förskollärarna använde sig av böcker i vilka de läste om naturvetenskapens bärande idéer och naturvetenskapens natur (Areskoug m. fl. 2013; Hamrin \& Norqvist 2005; Thulin, 2015). De bestämde sig för att arbeta med en konkret modell av rutschkanan i form av bänkar där den ena änden placerades i olika höjder för att ge barnen en känsla av höjd och hastighet när de åkte på bänkarna. Förskollärarna valde att förändra underlaget med hjälp av potatismjöl och en fleecefilt för att synliggöra friktionen. Vidare beslöt de introducera en för barnen mer abstrakt modell i form av ett lutande plan - en lutande bräda där barnen skulle kunna låta föremål glida för att reflektera om och diskutera det de själva upplevt med bänkarna. 



Aktivitet med barnen

Grupp 1- Git

5 tillfälle under veckan

Aktivitet med barnen

Grupp 2- Mia eller Lena

5 tillfälle under veckan

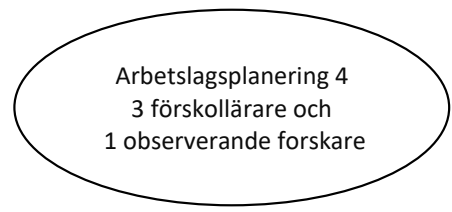

Figur 1. Schematisk figur över arbetslagsplaneringar och antal undervisningstillfälle $i$ två parallella barngrupper.

\section{Analys}

Videomaterialet från arbetslagets planeringssamtal har transkriberats i sin helhet. En fenomenografisk analys har genomförts med fokus på variationer av samtalsteman som rör intentionellt lärandeobjekt. Analysenhet är utsagor som kan bestå av en eller flera meningar. Utsagorna har kategoriserats utifrån centrala samtalsteman och de kan tillhöra mer än en kategori. Analysen avser synliggörande av hur det fysikaliska innehållet (det intentionella lärandeobjektet) konstrueras som lärandeobjekt under arbetslagets planeringssamtal. Samtalen behandlar planering av nästkommande undervisningstillfälle, i tre fall utifrån erfarenheter från föregående genomförande, se figur 1. 
Analysen har särskilt uttalanden om lärandets objekt för att i detalj analysera hur lärandeobjektet konstrueras. Vid analysen framkom fyra kategorier. Det som skiljer kategorierna ifrån varandra är vad som sätts i förgrunden i relation till lärandeobjekt av förskollärarna. Alla utsagor som kan relateras till vad barnen gjort eller ska göra är samlade i lärandeobjektets konstruktion - aspekter på barns utforskande. De utsagor som handlar om förskollärarnas kunskaper i relation till undervisningen i de studerade aktiviteterna tillhör kategorin lärandeobjektets konstruktion - kunnandets utveckling. De utsagor som betraktas ge uttryck för planeringsdokumentets betydelse finns i kategorin lärandets konstruktion - planeringsmatrisens påverkan. I kategorin lärandeobjektets konstruktion - betydelsen av modeller har förskollärarnas utsagor om olika redskap som använts vid undervisningen kategoriserats. Vid en närmare analys blir det synligt att respektive samtalstema/kategori innehåller ett mönster av utsagor som kan sorteras i olika antal underkategorier. Följande huvudkategorier med tillhörande underkategorier har identifierats:

- $\quad$ Lärandeobjektets konstruktion- aspekter på barns utforskande

- Lärandeobjektets konstruktion- kunnandets utveckling

-Utveckling av kunnande i naturvetenskap

-Utveckling av naturvetenskapligt didaktiskt kunnande

- Lärandeobjektets konstruktion- planeringsmatrisens påverkan

- Lärandeobjektets konstruktion- betydelsen av modeller

-Redskap i vardagsmiljön

-Bänkar som modell

-Lutande planet som modell

\section{RESULTAT}

I det följande presenteras resultaten. Innebörden i respektive kategori med tillhörande underkategorier presenteras och exemplifieras genom exempel på utsagor som styrker kategoriernas innebörd.

\section{Lärandeobjektets konstruktion - aspekter av barns utforskande}

Gemensamt för utsagorna i denna kategori är hur förskollärarna talar om aktiviteter som skett tidigare eller som ska ske och vad som krävs av respektive aktivitet för att sätta fokus på lärandeobjektet. Lärarna talar om något som är gjort tillsammans med barnen, har hänt i aktiviteten med barnen eller något som ska göras tillsammans med barnen och som påverkar det intentionella lärandeobjektet i någon riktning. Barns utforskande med fokus på hur de agerar i aktiviteterna bidrar till hur undervisningen av lärandeobjektet iscensätts. Det barn gör i aktiviteterna ses som uttryck för förståelsen av lärandeobjektet och bidrar till fortsatt planering av undervisning.

Git: och de åkte rutschkana i evigheter och de åkte alltså provade. De åkte sittande, de låg på mage, de låg på rygg, alltså så de utforskade lite. Så intresset finns ju.

Lena: $\mathrm{mm}$

Mia: $\mathrm{mm}$

Git: det är ju bara de naturvetenskapliga begreppen

Lena: $\mathrm{mm}$

Mia: ja men det var ju det samma som när de åkte med lutningen, att de lärde sig att håller man i kanten när man åker på bänkarna så gick det ju saktare. Det kom de ju, det var ju någonting som de själva uppmärksammade på. Att släpper det så går det snabbare och håller jag i så kan jag liksom nästan dra mig framåt. Det är ju något också man har med.

Git: ja ja, med hastigheten

Mia: ja med hastigheten

Förskollärarna tolkar det som de sett barnen göra i relation till lärandeobjektet. Att barnen använder sig av sin kropp för att visa sitt utforskande indikerar för förskollärarna en process kopplat till lärandeobjektet. 
Git: och sen också att dem får utforska i sin takt.

Mia: i sin takt

Git:.. och där kommer inte andra som ska åka så att de blir stressade och får flytta sig. Utan att de får verkligen prova, de får utmana sin kropp. De får känna efter hur det känns liksom, utforska, de har ju så mycket med att utforska sin kropp. Så att alltså, de måste ju utforska det först för att kunna ta till sig att höjden har ett samband med hastigheten. De har bara kommit till utforska mig själv och min kropp.

Förskollärarna ger uttryck för att barns utforskande är ett sätt för barnen att närma sig lärandeobjektet. De beskriver hur barnen måste få undersöka i sin egen takt för att få lugn och ro att utforska innehållet och lärandeobjektet. Utsagorna kan tolkas som ett uttryck för en syn där barn först måste få uppleva lärandeobjektet med kroppen innan de kan förstå själva lärandeobjektet, att det sker i olika steg. Detta innebär att det ges utrymme i undervisningen för barnen att prova aktiviteten flera gånger och vid flera tillfällen och att betydelsen av barns utforskande bidrar till att konstruera lärandeobjektet.

\section{Lärandeobjektets konstruktion - kunnandets utveckling}

I kategorin lärandeobjektets konstruktion- kunnandets utveckling har utsagor som ger uttryck för kunnandets betydelse i relation till förskollärares tredelade uppdrag som rör barns omsorg, fostran och lärande kategoriserats. Vid närmare analys framstod två underkategorier 1) utveckling av kunnande i naturvetenskap och 2) utveckling av naturvetenskapligt didaktiskt kunnande.

\section{Utveckling av kunnande i naturvetenskap}

Denna underkategori samlar förskollärarnas utsagor som kopplas till kunnande i naturvetenskap. Dels omfattar underkategorin utsagor som rör förskollärarnas eget kunnande i relation till planering av undervisning om lärandeobjektet, men även utsagor som rör hur deras kunnande utvecklats under arbetets gång. Förskollärarna beskriver hur de genom att de läst och utvecklat sitt kunnande inom naturvetenskapen, nu ser fysiken i vardagen på ett annorlunda sätt jämfört med tidigare. Att fysik kan vara en del av barnens vardag men även att deras attityd till innehållet förändrats. De beskriver att de genom ett större kunnande fătt en växande självkänsla att ta sig an fysik som innehåll.

Genom att läsa, som förskollärarna uttrycker det, "rätt litteratur" har intresset ökat och utsagorna visar att de vill utveckla sitt kunnande vidare då de ser många möjligheter till att arbeta med naturvetenskap.

Mia: jag känner, ens egen kunskap har ju ökat. Så att därför är det också lättare ta till vara på det i vardagen och synliggöra det för det har varit synligt hela tiden. Men det är bara att man inte riktigt har synliggjort det för att du inte själv haft kunskapen. Eller ja du har fått andra ögon och se det med, sen vissa grejer har man vetat men man har plockat upp det på ett annat sätt nu känner jag.

Lena: och det är ju tack vare det här projektet egentligen för annars hade vi ju inte stannat upp och gjort det, reflekterat på det sättet som vi gjort.

Git: nej, vi hade nog inte valt kraft så

Mia: nej

Lena: nej

Genom ett större kunnande i naturvetenskap beskriver förskollärarna att de inser hur mycket fysik det finns i vardagen och att det är ett innehåll de kan arbeta med för en lång tid framöver. Ett ökat kunnande inom naturvetenskap gör det möjligt att få syn på den i vardagen, vilket upplevs öka möjligheterna till ett fortsatt arbete med det naturvetenskapliga innehållet. En av förskollärarna beskriver en tidigare rädsla för innehållet och hur den genom ett nyfunnet kunnande nu inte längre blir ett hinder för arbetet: "Alltså vi kan jobba med fysik hur många år framåt som helst och det har man varit lite mer rädd för innan alltså så och inte kunnat ..." (Git). 
Ett annat sätt att använda litteraturen kommer till uttryck då den blir en del av planeringsdiskussionen i arbetslaget. Förskollärarna tar avstamp i litteraturen för att identifiera hur de ska arbeta med förklaringsmodellen med barnen.

Mia: så pratade vi om kraften..

Git: så var det ju..

Mia: hur vi ska förklara den?

Git: hur vi ska, skulle förklara och i boken här så står det "vi har konstaterat att vi nästan alltid har friktion mot underlaget alltså en kraft som verkar i motsatt riktning mot rörelsen och därför bromsar den”. Hur gör vi där? vad ska vi, vad ska vi kalla rörelsen så det blir enkelt?

Mia: Jag tänkte, det är ju kraften där som man, det är ju svårt för dem att förstå att den mot... (visar med sina händer)

Git: ja ja

Mia: att krafterna, får ena kraften åt ena hållet och den andra mot andra

Git: ska vi bara säga att det blir ett motstånd, att motståndet blir... att det blir ett mer motstånd eller mindre motstånd?

Utifrån litteraturen identifierar förskollärarna vilken förklaringsmodell de ska utgå ifrån i mötet med barnen. Den förklaringsmodell som de utrycker passar den barngrupp som är delaktiga i aktiviteten.

Genom förskollärarnas uttalande framkommer en bild av att det naturvetenskapliga kunnandet bidrar till att konstruera lärandeobjektet. Ett ökat kunnande bidrar till en positiv attityd som bidrar till att förskollärarna ser det naturvetenskapliga innehållet som en del av barnens vardag och att det finns mer inom fysik att arbeta vidare med. Det är även det utvecklade kunnandet som gör det möjligt för förskollärarna att se hur mycket fysik det finns i vardagen och att det skulle kunna vara föremål för undervisning framöver.

\section{Utveckling av naturvetenskapligt didaktiskt kunnande}

Fokus för denna underkategori är utsagor som rör förskollärarnas didaktiska kunnande kopplat till naturvetenskap. Dels omfattar kategorin utsagor som rör hur förskollärarna resonerar kring det didaktiska angreppssättet kopplat till undervisningen av lärandeobjektet, men även utsagor som rör det fokus som de olika förskollärarna har och hur det påverkar vad som kommer i förgrund respektive bakgrund i relation till lärandeobjektet.

Arbetslaget är inte överens om vad som bör komma i förgrunden i aktiviteten för att sätta fokus på lärandeobjektet. En uppfattning som uttrycks i diskussionen är att barnen måste få uppleva och utforska med sin kropp och att strukturella förutsättningar avgör hur aktiviteten genomförs. Strukturella förutsättningar i betydelsen att få tillgång till gymnastiksalen, gällande tidsram samt barns närvaro vid de olika tillfällena.

Lena: och du och jag var också uppe med de andra då, men vi hade inte dem uppe samtidigt. Utan vi tog ju, de fick ju åka varsin gång med..

Git: men sen tycker jag samtidigt att är det inte viktigt just för det pedagogiska att man ska kunna jämföra? Annars försvinner själva poängen med att göra det.

Mia: ja men vi hade inte möjlighet. För vi hade, vid det tillfället..

Lena: $\mathrm{mm}$

Git: nej

Mia: ..utan vi, där..

Lena: ..tillgång till salen

Mia: ..ja tillgång. Men vi, det blev att dem vi hade med oss upp, dem behövde åka mer för dem hade inte fătt det tillfället att göra det. Så därför pratade vi om att nu på torsdag när vi har idrottshallen att dem ska få göra det igen med filten, för att...

Git: fast där tycker jag det är svårt att åka mer, alltså det är bra att åka mer och lära sig utforska sin kropp...

Mia: ja 


\section{Hellberg, Thulin och Redfors}

En förskollärare ger uttryck för betydelsen av att barn får möjlighet att uppleva kontraster så att de kan få syn på variationer som hon anser är avgörande för erfarande av lärandeobjektet.

Git: men det är ju inte det som är målet med själva den här uppgiften, utan det är ju att se att den högre ger en snabbare hastighet...

Lena: jo men

Git: ..och har du bara en bänk..

Lena: Jo men för att kunna se det här så måste du använda kroppen. För det är ju det du utforskar med... du får känslan

Git: jo men du ser ju andra med som använder. Har du bara en så försvinner hela det pedagogiska perspektivet.

Mia: ja

Git: tycker jag

Lena ja eh..

Git: tycker jag.

Excerpten ovan visar också att det finns två fokus för hur lärandeobjektet bör tillgängliggöras. Dels uttrycks betydelsen av att barn lär genom att använda sin kropp (Lena) och dels synliggörs en lärandesyn om betydelsen av variation (Git).

Mia: ja fast vi pratade om, det var ju lite olika...

Lena: vilken nivå var på...

Mia: ja och vi kände att de var bra att de får. För vissa hade ju inte, ville ju inte åka överhuvudtaget så dem fick liksom, de var nog lite rädda för det också.

Lena: $\mathrm{mm}$

Mia: så då fick dem sin tid att öva.

Git: ja

Lena: de behövde mer tid för att göra detta

Git: men jag hade nog ändå haft två så de hade sett att det fanns en snabbare och en långsammare.

Lena: ja

Mia: ja

Git: nu tappar man själva poängen.

Mia: jag håller med dig att, men ser man till de förutsättningar som var..

Lena: som var i lokalen

Mia: så valde vi att inte, att ta att, de fick börja åka på grund av att vi hade nästan ingen tid överhuvudtaget där uppe så att..

Lena: och det var grejor fram plockade

Mia: ja

Git: ja det går väl bra, men det blir ju inte fysik!

I ovanstående excerpt synliggöras hur förskollärarna har olika fokus för aktiviteten kopplat till det lärandeobjekt som identifierats. Å ena sidan sätts fokus på att åka på bänkarna och vad som krävs för att det ska vara möjligt. En faktor som lyfts är att barnen måste känna en trygghet genom att få åka flera gånger. Detta synliggörs i utsagan av Mia som uttrycker att "så då fick de sin tid att öva". Detta förstärks av Lenas "de behövde mer tid för att göra detta". Det som kommer i förgrunden är själva åkandet på bänkarna och att känna en trygghet i det. För den tredje förskolläraren är det hur lärandeobjektet blir möjligt att urskilja, som kommer i förgrunden. Det synliggörs i hennes uttalande "men jag hade nog ändå haft två så de hade sett att det fanns en snabbare och en långsammare" och "nu tappar man själva poängen". Utsagorna ger inte en samlad bild kring vad som ska sättas i förgrunden och fokuseras i aktiviteten utan olika uppfattningar kvarstår.

Förskollärarna ger uttryck för hur kunnandet i naturvetenskap gett dem nya insikter och att det påverkat deras attityd till innehållet. Samtidigt framträder en bild av att förskollärarna inte ger ut- 
tryck för en samlad syn kring det didaktiska angreppssättet kopplat till det specifika innehållet, vilket påverkar hur undervisningen iscensätts i de två olika grupperna. Resultatet visar att såväl kunnande i naturvetenskap som naturvetenskapernas didaktik och båda dessa områdens relation till det specifika innehållet bidrar till konstruktionen av lärandeobjekt.

\section{Lärandeobjektets konstruktion - planeringsmatrisens påverkan}

Alla utsagor som kopplas till den aktuella förskolans planeringsmatris har kategoriserats i kategorin Lärandeobjektets konstruktion- planeringsmatrisens påverkan. Förskollärarna använder sig av en planeringsmatris med olika rubriker för all planering av aktiviteter med barn. Bland annat identifieras målet med aktiviteten, kopplingen till förskolans läroplan och vad barnen lärt sig.

Git: och då var det på utveckling och lärande

Lena: du har också det här att utveckla sin förståelse för naturvetenskap och samband i naturen, fysikaliska fenomen, där är ju också med

Git: men jag tycker dem har visat begreppsbildning där

Mia: ja

Lena $\mathrm{mm} \mathrm{mm}$

Git: tycker jag

Lena: jo jo, det tycker jag med

Mia: några stycken

Lena: några stycken, inte alla men några har ju gjort det

Git: alla har ju visat att dem förstår. Alltså de har förstått att det går snabbare med vattnet...

Lena: snabbare med vattnet.

Git:.det är ju ingen som inte förstår det

Lena: ja nej

I ovanstående excerpt ges inga argument eller konkretiseringar som synliggör hur de vet att barnen utvecklat respektive förmågor. Möjligen kan förskollärarnas utsagor förstås som att de uppfattas ha en gemensam bild kring barns utveckling av förmågor och lärande. Det kan tolkas som att när det inte finns en rubrik som uppmanar förskollärarna att diskutera eller beskriva hur de vet att barnen utvecklat förmågor kommer inte detta i förgrunden i diskussionen vilket resulterar i att de inte diskuterar det.

Utsagorna visar att planeringsmatrisen används för att gemensamt sätta ord på målet med undervisningen och för att utgå ifrån tidigare aktiviteter i planeringen av kommande undervisning. Den uppfattas också fylla en funktion som dokumentation av barns lärande, men planeringsmatrisen ger inte utrymme för diskussioner som ger stöd åt vissa av de utsagor som till exempel hur de vet att barnen utvecklat sina förmågor. Genom användandet av planeringsmatrisen behandlas ett visst innehåll under arbetslagsplaneringen i relation till de rubriker som finns angivna i matrisen vilket leder till att vissa innehåll fokuseras och diskuteras. Det som behandlas och ges utrymme i diskussionen utifrån planeringsmatrisen rubriker är det som bidrar till konstruktionen av lärandeobjektet och den planerade undervisningen. På så sätt styr planeringsmatrisen samtalet och påverkar vad det blir av det specifika innehållet.

\section{Lärandeobjektets konstruktion - betydelsen av redskap och modeller}

Fokus i denna kategori är hur förskollärarna talar om de olika redskap som används vid undervisning av det naturvetenskapliga innehållet. Arbetslaget har använt sig av rutschkanor, bänkar och ett lutande plan för att synliggöra lärandeobjektet i mötet med barnen. Rutschkanan representerar en del av barnens vardagsmiljö. Bänkarna och det lutande planet blir modeller av den verkliga rutschkanan i syftet att synliggöra lärandeobjektet kraft och specifikt friktion. Förskollärarna utnyttjar de redskap som finns tillgängliga. I början fanns tillgång till bänkar som användes på den egna förskolan. När det inte längre var möjligt att låna dessa fick förskollärarna och barnen i stället besöka gymnastiksalen en bit bort från förskolan. Nedan följer underkategorier som beskriver de olika redskap som används i undervisningen av det fysikaliska lärandeobjektet. 


\section{Redskap i vardagsmiljön}

Kategorin omfattar utsagor som rör när barnen făr möjlighet att genom olika redskap i miljön erfara innehållet på olika sätt i utomhusmiljön. Förskollärarna återkommer till en erfarenhet som hänt innan de började arbeta med temaarbetet kring kraft och friktion. Deras utsagor beskriver hur backen som utforskades tillsammans med barnen har begränsningar för att kunna skapa förståelse av det tänkta lärandeobjektet. Förskollärarnas utsagor ger en indikation på att när backen inte möter förväntningarna för att kunna genomföra aktiviteten leder detta till att andra redskap blir aktuella, i detta fall rutschkanan. Vidare diskuteras hur de med hjälp av rutschkanan och olika material kan sätta fokus på lärandeobjektet.

Git: ja, det är ju perfekt och potatismjöl och både potatismjöl och..

Mia: potatismjöl på den (visar med handen som på en bänk)

Git: ja och vatten är lätt att ta med sig ut till de andra rutschkanorna om det inte råkar regna eller snöa eller andra naturkrafter.

Mia: det hade ju varit det bästa egentligen, om det hade regnat. Då får man det ju i....

Git: jo om det bara regnar så kan man ju satsa stenhårt på det. Det kan ju i och för sig vara bra och ha med också och tydliggöra vad vi gör, bägge delar är ju bra.

Lena: ja men också vi sa, att vi skulle ha plastpåse eller någonting att åka på. För att tydliggöra det, det är svårare att förstå det här med kläderna. Att olika ytor, att det och det, att det blir bättre.

Git: absolut, det är bättre att ha ett material

Lena: att det är samma material att åka på.

Utsagan "ja och vatten är lätt att ta med sig ut till de andra rutschkanorna om det inte råkar regna eller snöa" visar att de använder sig av olika material för att skapa friktion.

\section{Bänkar som modell}

Fokus för denna underkategori är förskollärarnas utsagor som kopplas till redskap som representeras av bänkar. Bänkarna används för att synliggöra att höjden påverkar hastigheten, vilket kan utläsas av följande utsaga: men det är ju inte det som är målet med själva den här uppgiften, utan det är ju att se att den högre ger en snabbare hastighet (Git). Bänkarna används även för att synliggöra att olika material påverkar friktionen. Detta är en tillrättalagd verklighet för att få möjlighet att uppleva lärandeobjektet. I samband med att bänkarna används är det barnen själva som är aktiva och upplever innehållet med sin egen kropp. I nedanstående utsagor skildras vad som skett när en av förskollärarna haft en aktivitet. I aktiviteten används bänkarna och potatismjöl för att påverka friktionen.

Lena: mmm vad hände då när de använde det på bänken?

Git: Ja alltså, händerna då. På bänken sögs det ju upp på kläderna så det blev ju inte halt Mia: men var alla, jag tänkte på det sen också, var alla kläder, för jag tänkte på de som hade jeans och sådant. Där är ju större räfflor, där kan jag tänka att det, men var det någon skillnad....

Git: nej nej

Mia: ....beroende på vilka kläder de hade?

Git: nej jag tyckte inte någon åkte snabbt

I förskollärarnas utsagor kan de tolkas som att syftet de haft med aktiviteten och bänkarna som redskap inte uppfyllt deras förväntningar. I nedanstående utsagor beskrivs hur bänkarna fyller en fortsatt funktion för att synliggöra lärandeobjektet för barnen.

Lena: men nu när jag kom tillbaka då gick vi ju. Då fick vi möjlighet att vara i gympasalen och då gick vi ju upp och då hade vi ju den gröna filten fleecefilten med.

Git: ja den tyckte jag blev väldigt tydlig

Lena: ja

Git: den var ju bra för den var tjock och luden, det blir tydligt att det blir motstånd att det ger friktion, mycket friktion 
Lena: och det tror jag var uppenbart för dem som var med då.

Git: ja ja

Bänkarna som redskap används kopplade till lärandeobjektet. Det kan tolkas som att bänkarna möjliggör flera olika fokus i de olika undervisningstillfällena. Med hjälp att bänkarna som redskap kan förskollärarna iscensätta olika undervisningstillfällen för att fokusera på lärandeobjektet.

\section{Lutande plan som modell}

I denna underkategori ingår förskollärares utsagor kring det lutande planet. Det lutande planet är en representation av det som barnen upplevt med bänkarna. De väljer att iscensätta det lutande planet på ett sätt så att det ska likna aktiviteten i gympasalen. Det gör de genom att försöka efterlikna de material som används på bänkarna i aktiviteten med det lutande planet.

Mia: men Lena, vi kan lösa det själva för den är ju så här bred. Och tar du den då, som där är skumgummi som vi har pratat om att det är filten, så tar du bara sånt här brett genomskinligt tejp och så lägger två remsor tejp så har du en med lite uppe och så har du en bredvid.

Lena: på samma plan

Mia: ja på samma plan för vi har ju sådan bred genomskinlig tejp

Lena: ja den

Mia: där är ju mindre friktion än tyg det är bara att tejpa uppepå för det är ju lätt att ta bort...

Förskollärarnas uttalande kan tolkas som att det ligger ett fokus på att erbjuda redskap som ska vara igenkänningsbara för barnen genom att det lutande planet ska efterlikna aktiviteten med bänkarna i form av material och utseende. Förskollärarna ger även uttryck för att det lutande planet kan vara till grund för att låta barnen diskutera och reflektera över det som de varit med om och upplevt med bänkarna.

Git: men sen tror jag också att om vi gör, alltså det lutande planet när man sitter inne så är det lätt att se vilka som har förstått det här med lutningen och hastigheten. Och lättare att se också kanske, i ett litet format

Mia: ja

Git: utan för sig själv

Uttalandet ovan kan tolkas som att förskollärarna förutsätter att barnen gör en abstrakt koppling mellan det de upplevt med bänkarna och det som de ska samtala om vid lutande planet.

I ovanstående kategorier ger förskollärarna uttryck för att i arbetet med ett innehåll skapas olika förutsättningar beroende på de redskap som finns tillgängliga. Förskollärarna talar om dessa redskap i sin planering av undervisningen som grundläggande i barnens aktivitet för att kunna sätta fokus på lärandeobjektet. Genom förskollärarnas utsagor kan det tolkas som att de redskap som förskollärarna finner tillgängliga bidrar till konstruerandet av lärandeobjektet.

\section{DISKUSSION}

I fokus för denna studie är ett arbetslags planeringsdiskussioner. Det som sägs och ges utrymme under diskussionerna kan betraktas som föreställningar, värderingar och upprätthållande av normer kopplade till den kultur, som förskollärarna verkar i (Linell, 1982). I samtalet bidrar enskilda förskollärare med sina olika idéer och erfarenheter, vilka de andra responderar på och detta leder till konstruktionen av lärandeobjektet. Syftet med denna studie är att utveckla kunskap om hur ett fysikaliskt lärandeobjekt konstrueras i förskolans kontext. Resultaten pekar på att aspekterna kunnandets utveckling, barns utforskande, betydelsen av modeller och planeringsmatrisens påverkan bidrar till konstruktionen av det aktuella lärandeobjektet. Nedan kommer de olika aspekterna att diskuteras i respektive avsnitt. Med utgångspunkt i studiens resultat och diskussion presenteras avslutningsvis möjliga implikationer för förskolans verksamhet. 
Genom förtydligandet i förskolans läroplan fick förskolan ett vidgat uppdrag gällande naturvetenskap (Utbildningsdepartementet, 2010). En aspekt som blivit synlig är att förskollärarna upplever att ett vidgat kunnande om naturvetenskap påverkar såväl deras attityd till kunskapsområdet som planering och genomförande av undervisning. Litteratur har bidragit till en förändrad syn på innehållet, förändrad attityd och utvecklat förskollärarnas egen förståelse av lärandeobjektet, vilket i sin tur över tid påverkat konstruktionen av objektet. Förståelsen av lärandeobjektet innebär att förskollärarna kan se möjligheter i vardagen för att arbeta med lärandeobjektet. Förskollärarnas utvecklade kunnande kan medverka till en positiv attityd till innehållet, vilket kan bidra till att barnen får positiva förebilder och att ett intresse för naturvetenskap utvecklas hos barnen (jfr. Pramling Samuelsson \& Sheridan, 2016). Det empiriska materialet visar att förskollärarnas uttalanden kan förstås som att vid ett ökat kunnande ökar också intresset för att naturvetenskap ges ett större utrymme i undervisningen. I takt med att förskollärarna förstår innebörden i det fenomen de valt ser de mer möjligheter med fysik och innehållet ges mer utrymme i diskussioner som konstruerar lärandeobjektet.

Även om kunnandet om naturvetenskap kan ses som bidragande faktor till undervisningen kring fenomenet är detta inte den enda avgörande faktorn. I likhet med andra studier (Pramling Samuelsson \& Sheridan, 2016; Thulin \& Redfors, 2017) riktar resultatet uppmärksamhet mot att det är kunskapen kring barn, lärande och innehåll som bidrar till lärandeobjektets konstruktion. Även om förskollärarna i studien identifierar en gemensam förklaringsmodell (jfr. Redfors, 2016) för aktuellt fenomen verkar det saknas en gemensam syn på hur undervisningen bör genomföras då förskollärarna har olika kunskapsteoretiska utgångspunkter. Medan en förskollärare framhåller vikten av variation för att synliggöra samband, förordar en annan barns kroppsliga utforskande. Beroende på vem av förskollärarna som genomför undervisningen finns olika fokus för aktiviteten där det didaktiska förhållningssätt som praktiseras riskerar att skifta lärandeobjekt och barnens medvetanderiktning. Respektive förskollärares förhållningssätt kommer till uttryck först i och med respektive aktivitets genomförande och förblir oproblematiserade under arbetslagssamtalen. Resultaten visar därmed att intentionella objekt för lärande riskerar att osynliggöras och eller förändras inte bara över tid utan också i relation till vem som ansvarar för undervisningen i en aktuella situation.

Förskollärarnas respektive didaktiska angreppssätt kan också ses som ett uttryck för olika sätt att se på sitt uppdrag och på vad barn i förskola kan och ska lära sig, vilket i sin tur påverkar arbetet med det fysikaliska fenomenet och barns möjlighet att urskilja aktuellt objekt för lärande. Detta kan jämföras med andra studier (Fleer, 2009: Nordenbo m. fl., 2008; Thulin, 2011; Thulin \& Redfors, 2017) som beskriver att förskollärares kompetens handlar om såväl innehållskunskaper som kunskap om barns lärande. Resultatet från denna studie visar att utöver en gemensam förklaringsmodell kan val av didaktiskt angreppssätt bidra till hur lärandeobjektet konstrueras i förskolan med de yngsta barnen och kan jämföras med Thulin (2011) och Fleer (2009) som visar att förskollärares kunskaper om och inställning till naturvetenskap och didaktik får konsekvenser för hur innehållet hanteras vid undervisning av det fysikaliska lärandeobjektet.

Barns utforskande är ytterligare en aspekt som tycks bidra till konstruktionen av lärandets objekt. Genom att dels erbjuda utforskande aktiviteter samt att dels observera barns agerande i aktiviteterna kan förskollärarna få syn på var barnen befinner sig - vad de riktar sin uppmärksamhet mot - och utifrån det planera lärandeobjektets fokus. Det barnen har gjort i tidigare aktiviteter bidrar till att förskollärarna avgör vad som blir nästa steg. Barnen ges till exempel mer tid till att utforska och uppleva för att kroppsligen närma sig lärandeobjektet. Resultaten visar att det finns en önskan hos förskollärarna om att det lärandeobjekt som väljs skall erbjuda stöd för barns eget utforskande. Å andra sidan visar inte förskollärarnas utsagor hur de ser på sin egen roll i denna process och hur de ska agera för att sätta de innehållsliga aspekterna i förgrunden. Detta kan diskuteras i relation till Larsson (2016) som visar att lärarna i hennes studie inte alltid möter barns engagemang så att innehållsliga aspekter av det fysikaliska fenomenet kommer i förgrunden. Förskollärarna i denna studie tillskriver under de studerade planeringssamtalen barns utforskande stor betydelse vid undervisning av valt lärandeobjekt. I ljuset av resultaten från Larssons (2016) forskning kan frågor ställas vad som är möjligt för barnen att få syn på i den reella undervisningssituationen och om förskollärarna bemöter barnen didaktiskt så att de får syn på lärandeobjektet. 
En modell av ett lutande plan används för att skapa förutsättningar för barnen att reflektera och sätta ord på sin förståelse kring lärandeobjektet. Att barn får möjlighet till reflektion och att forma sin förståelse beskriver Larsson (2013) är bidragande till kunskapsutveckling av naturvetenskapliga fenomen. Studiens resultat visar att tillgången till redskap i förskolans miljö och vad de erbjuder för möjligheter att utnyttjas i relation till undervisning om valt lärandeobjekt påverkar hur det fysikaliska fenomenet kan synliggöras och upplevas kroppsligt. De redskap som finns tillgängliga i förskolans vardagsmiljö utgör en bidragande aspekt till konstruktionen av lärandeobjektet.

En annan bidragande aspekt till konstruktionen av lärandets objekt är den planeringsmatris som användes av arbetslaget. Planeringsmatrisen används av alla arbetslag på den aktuella förskolan och syftar till att bidra till det systematiska kvalitetsarbetet med fokus på förskolans pedagogiska ansvar. Utifrån de diskussioner i arbetslaget som studerats kan planeringsmatrisen upplevas ha fördelar då den fungerar som ett redskap för att hålla fokus på den pedagogiska diskussionen. Samtidigt visar resultaten från denna studie att den kan fungera begränsande då matrisens förutbestämda rubriker kan ses som styrande för vad som diskuteras. Användningen av planeringsmatrisen bidrar till att konstruera lärandeobjektet genom att den påverkar diskussionen i en viss riktning. Planeringsmatrisen, som nyttjas under samtalet, förefaller inte stödja förskollärarna till en gemensam hållning kring hur undervisningen ska genomföras, den är alltför generell i sina rubriker och tycks inte bidra till fördjupande diskussioner kring till exempel perspektiv på lärande, vilket i sin tur riskerar att påverka konstruktionen av lärandets objekt.

\section{IMPLIKATIONER}

Ovan nämnda aspekter som kan ses bidra till konstruktionen av lärandeobjektet är kopplade till den kontext och de deltagare som studerats. Det är en komplex process med flera perspektiv som samtidigt spelar in och bidrar till konstruktionen. Resultaten visar att konstruktionen är rörlig utifrån vad som händer i aktiviteten med barnen, tillgängliga redskap på den aktuella förskolan, förskollärarnas kunskapssyn och förskollärarnas utvecklade förståelse av lärandeobjektet. Det handlar om ett kunnande hos förskollärarna kring barn, lärande och innehåll (jfr. Thulin \& Redfors, 2017) som behöver utvecklas samtidigt i relation med varandra. När utrymme ges för detta visar denna studie att det finns goda förutsättningar för att implementera naturvetenskapliga lärandeobjekt i förskola och med de yngsta barnen. Att förskollärarna inte har samma didaktiska angreppssätt kan bero på olika lärandesyn hos dem, vilket innebär att ömsesidig samtidighet inte alltid nås under arbetslagsplaneringen.

För att bidra till en gemensam hållning kring vad som ska komma i förgrunden under undervisningen behöver en ömsesidig samtidighet nås där varje förskollärare försöker inta de andras perspektiv samtidigt som de håller lärandeobjektet som barnen ska få utveckla kunnande kring i fokus (jfr Thulin, 2011). Vidare visas att användning av en planeringsmatris påverkar arbetslagsdiskussionen och konstruktionen av lärandeobjektet, vilket, utifrån denna studie, innebär att dylika dokument är centrala för kvalitetsarbete inom förskola.

\section{TACK}

Denna forskning är en del av den nationella forskarskolan i kommunikation och relationer som grundläggande för förskolebarns lärande (FoRFa), finansierad av Vetenskapsrådet (nr. 729-2013-6848).

\section{LITTERATURFÖRTECKNING}

Areljung, S., \& Sundberg, B. (2018). Potential for multi-dimensional teaching for 'emergent scientific literacy' in pre-school practice. Journal of Emergent Science, 15, 20-27.

Areskoug, M., Ekborg, M., Lindahl, B., \& Rosberg, M. (2013). Naturvetenskapens bärande idéer: för lärare F-6. Malmö: Gleerups utbildning. 
Campbell, C., \& Spelderwinde, C. (2018). Teaching science in Australian bush kindergartens: Understanding what teachers need. Journal of Emergent Science, 15, 37-45.

Eshach, H., \& Fried, M. N. (2005). Should science be taught in early childhood? Journal of Science Education and Technology, 14 (3), 315-336. doi:10.1007/s10956-005-7198-9.

Fleer, M. (2009). Supporting scientific conceptual consciousness or learning in 'a Roundabout way' in play-based contexts. International Journal of Science Education, 31(8), 1069-1089. doi:10.1080/09500690801953161.

Gustavsson, L., \& Thulin, S. (2017). Lärares uppfattningar av undervisning och naturvetenskap som innehåll i förskolans verksamhet. Nordic Studies in Science Education, 13(1), 81-96. doi:10.5617/nordina.2549

Halldén, G. (2007). Barndomssociologi och möjligheten av ett psykosocialt perspektiv. I G. Halldén (Red.) Den moderna barndomen och barns vardagsliv. Stockholm: Carlssons.

Hamrin, M., \& Norqvist, P. (2005). Fysik i vardagen: 257 vardagsmysterier avslöjade över en kopp kaffe. Lund: Studentlitteratur.

Harlen, W. (Ed.) (2010). Principles and Big Ideas of Science Education. Hatfield: ASE.

Larsson, J. (2013). Contextual and Conceptual Intersubjectivity and opportunities for emergent science knowledge about sound. International Journal of Early Childhood, 45(1), 101-122. doi; 10.1007/s13158-012-0078-6.

Larsson, J. (2016). När fysik blir lärområde i förskolan. Göteborg: Acta universitatis Gothoburgensis.

Linell, P. (1982). Människans språk: en orientering om språk, tänkande och kommunikation. (2. uppl.) Lund: LiberLäromedel.

Lo, M. L. (2014). Variationsteori: för bättre undervisning och lärande. 1. uppl. Lund: Studentlitteratur.

Marton, F., \& Booth, S. (2000). Om lärande. Lund: Studentlitteratur.

Marton, F., Runesson, U., \& Tsui, A. B. M. (2004). The space of learning. I F. Marton \& A. B. M. Tsui (Eds.) Classroom discourse and the space of learning (s. 3-40). New York: Routledge

Nordenbo, S-E., Søgaard Larsen, M., Tiftikçi, N., Wendt, R. E., \& Østergaard, S. (2008). Lærerkompetencer og elevers læring i førskole og skole. Et systematisk review udført for Kunnskapsdepartementet, Oslo. Køpenhamn: Danmarks Pædagogiske Universitetsskole.

Oskarsson, M. (2011). Viktigt - men inget för mig: ungdomars identitetsbygge och intresse för naturvetenskap. Linköping: Linköpings universitet.

Pramling Samuelsson, I., \& Sheridan, S. (2016). Lärandets grogrund: perspektiv och förhållningssätt i förskolans läroplan. 3. uppl. Lund: Studentlitteratur.

Redfors, A. (2016). Att arbeta med teoretiska förklaringsmodell i förskolan. I Thulin, S. (Red.) Naturvetenskap i ett förskoleperspektiv: kreativa lärandeprocesser. Malmö: Gleerups Utbildning $\mathrm{AB}$.

Skolinspektionen (2018). Slutrapport. Förskolans kvalitet och måluppfyllelse - ett treårigt regeringsuppdrag att granska förskolan. Stockholm: Skolinspektionen.

Skolverket (2010a). Läroplan för förskolan Lpfö 98. Reviderad 2010. Stockholm: Skolverket.

Skolverket (2010b). Perspektiv på barndom och barns lärande: en kunskapsöversikt om lärande i förskolan och grundskolans tidigare år. Stockholm: Skolverket.

Skolverket (2016). Pisa 2015. 15-åringars kunskaper i naturvetenskap, läsförståelse och matematik. Stockholm: Skolverket

Thulin, S. (2011). Lärares tal och barns nyfikenhet: Kommunikation om naturvetenskapliga innehåll i förskolan. Göteborg: Acta universitatis Gothoburgensis

Thulin, S. (2015). Göra naturvetenskap i förskolan - med fokus på kommunikation. Stockholm: Liber

Thulin, S., \& Redfors, A. (2017). Student preschool teachers' experiences of science and its role in preschool. Early childhood education journal, 45(4) 509-520. doi: 10.1007/s10643-016-0783-0

Utbildningsdepartementet (2010). Regeringens promemoria inför revideringen av Lpfö98. U2010/4443/S. Hämtad 25 september, 2018 från regeringen.se. Websida: http://www.regeringen.se/regeringsuppdrag/2010/o8/u20104443s/ 